\title{
RELATIONSHIP BETWEEN PATTERNS FOR BABY'S HEAD
}

\author{
Agus Widodo'), Vivi Anggraini Sulistyaningtyas') \\ Edy Waspada ${ }^{3)}$, Arif Kurniawan ${ }^{4)}$ \\ 1) lecturer of physiotherapy specialization pediatric university muhammadiyah surakarta \\ 2) Bachelor of Physiotherapy University of Muhammadiyah Surakarta \\ 3) Clinical Editor and Practitioner of Pediatric Physiotherapy YPAC Surakarta \\ ${ }^{4)}$ Clinical Educator and Practitioner of Pediatric Physiotherapy PNTC Karangayar \\ Corresponding author: aw290@ums.ac.id
}

\begin{abstract}
Babies born today will normally have an oval head shape because they have to pass through the birth canal. The size of the baby's head will continue to grow, because the baby's skull is still malleable, it is too long to spend time in one same position could lead to changes in the baby's head shape. Therefore, the optimal form of development that parents are very influential, namely in the patterns of parenting a newborn. Among infant sleep position, the use of baby bedding, baby feeding positions, baby's pillow. Determine the relation of parenting to the shape of the baby's head.

This study is an sresearch observational withmethod. cross sectional The sampling technique used purposive sampling with 66 respondents. Data collected by filling the questionnaire and observation baby's head shape. The observations categorized by shape of the baby's head.

Observations done on 66 respondents, ie 39 respondents have normocephaly head shape,15 respondents have plagiochepaly head shapes, 6 respondents have scaphocephaly headshape, and 6 respondents have brachycephaly head shape.There is a relation parenting to the baby's head shape, including normocephaly, scaphocephaly, plagiocephaly, brachycephaly.
\end{abstract}

\section{Kata Keywords: Baby Parenting, Shape Head Baby}

\section{Introduction}

The fastest growth and development of a baby when the baby is 0-1 years old is the golden age of the baby in growth. So, it can be carried out monitoring growth and development at that age. Abnormalities can be known early and can be treated immediately to avoid severe abnormalities. Growth and monitoring can be done well if parents know the characteristics and principles of baby growth and development (Waani \& Pusmaika, 2015).

The shape of the head and face shape is not only a hereditary factor that influences it, but is the result of the interaction of several factors including the environment being one of the main causes of the slow growth of children. Head circumference measurement is important to determine the shape of the head which can be used as an indicator of head bone development and also related 
to brain growth and development, especially in children with mental retardation (Elianora, Sutardjo, \& Rianto, 2011)

Babies born normally will have an oval head shape, because the baby must pass through the birth canal. There is a soft area on the baby's head that will be seen. This area is called frontanels (crowns) which help the baby through a narrow birth canal. These frontanels will harden naturally when they have 6-20 months. The size of the baby's head will continue to grow, therefore because the baby's skull is still easy to form, spending a lot of time on the same position results in changes in the shape of the baby's head (Speltz, Heike, Cunningham, Gray, \& Starr, 2012).

As many as $30 \%$ of all babies have plagiocephaly deformational, also known as positional plagiocephali. The results of this study indicate that children with deformed plagiochepaly experience delays in growth and development compared to normal children. Growth and development delays that occur in motor skills such as balance, jumping and running, language and cognition measures (Speltz, Heike, Cunningham, Gray, \& Starr, 2012). There were $40 \%$ of cases of plagiocephaly, $10 \%$ of scapocephaly, $10 \%$ of brachyocephaly from the results of the preliminary survey that was done.

\section{Methods}

This research is an observational research type using cross sectional method. The sampling technique used purposive sampling as many as 66 respondents in 9 posyandu in Gumpang Village. The independent variable is the assuh pattern, while the variable is the shape of the baby's head.

\section{Results And Discussion}

This research was conducted in 9 posyandu toddlers found in Gumpang Village on 12-24 February 2018. The respondents of this study were 66 infants aged 0-6 months who were taken using purposive sampling technique.

Table 1. Characteristics of research respondents by sex

\begin{tabular}{ccc}
\hline By sex & amount $(\mathrm{n})$ & percentage $(\%)$ \\
\hline Male & 24 & 36,4 \\
Female & 42 & 63,6 \\
\hline Total & 66 & 100.0
\end{tabular}

Distribution of respondents based on sex, shows that the number of female respondents is 42 with a percentage of $63.6 \%$. This shows that the number of female respondents is more than female respondents

Table 2. Characteristics of respondents based on age

\begin{tabular}{ccc}
\hline Month (bulan) & amount $(\mathrm{n})$ & Percentage $(\%)$ \\
\hline 1 & 5 & 7,6 \\
2 & 11 & 16,7 \\
3 & 12 & 18,2 \\
4 & 7 & 10,6 \\
5 & 9 & 13,6 \\
6 & 22 & 33,3 \\
\hline
\end{tabular}


Distribution of respondents based on age shows that the number of respondents aged 1 month 5 infants with a percentage of $7.6 \%$. Respondents aged 2 months were 11 babies with a percentage of $16.7 \%$. Respondents aged 3 months 12 infants with a percentage of $18.2 \%$. Respondents aged 4 months 7 babies with a percentage of $10.6 \%$. Respondents aged 5 months 9 infants with a percentage of $13.6 \%$. Respondents aged 6 months were 22 infants with a percentage of $33.3 \%$. This shows that most respondents are 6 months old.

Table 3. Characteristics of respondents based on birth history Birth History Amount (n) $\%$ Percentage

\begin{tabular}{|c|c|c|}
\hline Birth History & amount(n) & Percentage $\%$ \\
\hline Born normally & 51 & 77,3 \\
\hline Cesarean & 15 & 22,7 \\
\hline & 66 & 100,0 \\
\hline
\end{tabular}

Table 4. Characteristics of respondents based on the shape of the respondent's head

\begin{tabular}{ccc}
\hline Head shape & amount $(\mathrm{n})$ & percentage $\%$ \\
\hline Normocephaly & 32 & 48,5 \\
Scaphocephaly & 9 & 13,6 \\
Plagiocephaly & 16 & 24,3 \\
Brachycephaly & 9 & 13,6 \\
\hline & 66 & 100,0
\end{tabular}

Respondent distribution based on the shape of the respondent's head there were 32 respondents with a percentage of $48.5 \%$ of respondents had a normocephaly head shape.

\section{a. Characteristics of respondents' education level}

The distribution of education levels of mothers of respondents is 2 people with a percentage of $3.0 \%$ of elementary school graduates. 6 people with a percentage of $9.1 \%$ junior high school graduates. 45 people with a percentage of $68.2 \%$ of high school graduates. 2 people with a percentage of $3.0 \%$ of D3 graduates and 11 people with a percentage of $16.7 \%$ of undergraduate graduates. This can be seen at the highest level of mother's education is SMAD Respondent's distribution based on the shape of the respondent's head there are 32 respondents with a percentage of $48.5 \%$ of respondents have a normocephaly head shape.

\section{b. Baby's head shape}

The results showed that the number of respondents who had a normochepaly head shape was 32 babies $(48.5 \%)$. The results of the analysis of the relationship of the bed to the shape of the head with the rank spearman correlation test $\mathrm{p}$ or sig value. (2-tailed) of $0,000(\mathrm{p}$ $<0,05)$ so that it can be reduced there is a relationship between sleeping position and head shape. Strength of the relationship between sleeping position and head shape with the $r$ or correlation coefficient of -0.947 . This means that the relationship between variables is perfect correlation. The minus sign (-) means the 
relationship is negative or inversely proportional.

This is in line with research conducted by (Nurlia, 2014) which states that there is a relationship between sleep habits and the shape of the baby's head, including the shape of the head of brachycephaly and scaphocephaly. The baby's sleep position has an impact on the development of the head shape. Changes in the baby's sleeping position, especially the supine sleeping movement, and tilted in a balanced manner will get a normal head shape (Hummel \& Fortado, 2006). Other studies also say that supine sleeping positions are an important determinant of plagioceplaly deformation (Hutchison, Hutchion, Thompson, \& Mitchell, 2004).

The results of the review above can be concluded that a good baby's sleeping position is with the supine sleeping position and right and left slant balanced to get the normochephaly head shape, if the baby is accustomed to 1 side sleeping position then parents must pay attention and change the child's sleeping position so it does not happen changes in the shape of the baby's head are not normochephaly.

\section{c. Sleeping pad on the shape of the baby's head}

The results of the analysis of the relationship of the bedding to the shape of the head with Spearman rank correlation test on the head base and the shape of the baby's head p or sig value. (2tailed) of $0,000(p<0.05)$ so it can be concluded that there is a relationship between the beds and the shape of the baby's head. The strength of the relationship is indicated by the value of the Correlation Coefficient of 0.882. This means that the relationship is perfect correlation. A positive sign $(+)$ specifies that the relationship is unidirectional.
Babies sleeping with parents / bedsharing are commonly used by mothers to facilitate breastfeeding. Breastfeeding and sharing a bed are very relevant in the first 6 months of birth (Blair \& Ball, 2004). Sharing a bed with a baby is a mother's choice to facilitate breastfeeding, this is related to the frequency of breastfeeding at night (MCCOY et al., 2004). Baby cribs should use a flat base and not too soft (Putri \& Soebadi, 2014).

The results of the above review can be concluded that bedding can affect the shape of the baby's head. A sleeping pad for babies should not be too soft and smooth to produce a normochephaly head shape. If the baby's bedding is too soft, it will affect the shape of the baby's head because the shape is uneven because it is too soft.

d. Breastfeeding position on the shape of the baby's head

The results of the analysis of the relationship of the bed to the shape of the head with Spearman rank correlation test in the sleeping position with the shape of the baby's head $\mathrm{p}$ or sig value. (2-tailed) of $0,000(p>0.05)$ so that the relationship between the position of breastfeeding and the shape of the baby's head. The strength of the relationship is indicated by the $r$ or pearson correlation value of -0.875 . This means that the relationship between variables is perfect correlation. The minus sign $(-)$ indicates that the relationship is negative or inversely proportional.

It is recommended that breastfeeding mothers sleep on their side or sit with their back and legs positioned to maximize breastfeeding. The baby's body must be exposed to the mother's body and her mouth is faced with the mother's nipple. The baby's neck should be slightly raised. The baby should be supported on his shoulder so that the head's slightly 
raised position can be maintained. The baby's head can be supported by the fingers of the supine hand or on the elbow of the mother's elbow (Iqbal, 2013).

The above statistical results can be concluded that normochephaly head formation can be influenced by the wrong breastfeeding position. The correct breastfeeding position for normochephaly head formation with a position of breastfeeding 2 sides in a balanced manner so that the head does not experience pressure on one side only when in the process of breastfeeding.

e. The base of the head against the shape of the baby's head

The results of the analysis of the Spearman rank correlation test on the head base and the shape of the baby's head $\mathrm{p}$ or sig value. (2-tailed) of $0,000(\mathrm{p}>$ $0,05)$ These results can be concluded that the base of the head is related to the shape of the baby's head. The strength of the relationship is indicated by the value of the $\mathrm{R}$ or Correlation Coefficient of 0.441 . This means that the relationship between variables is a moderate correlation. A minus sign (-) means that the relationship is negative or inversely proportional. In newborn babies do not need a pillow just using a thin diaper fold as a baby's head mat (T.M Indiarti, 2008).

The above statistical results can be concluded that babies should not sleep using pillows, so that the baby is more easily change the position of the head when sleeping. It is to get a normochephaly head shape. If the baby sleeps using a pillow, the baby will have difficulty changing the position of the baby's head so that the baby sleeps in one position and results in changes in the shape of the baby's head such as brachicephaly, scaphocephaly, and plagiochephaly.

\section{Conclusions}

Based on statistical analysis, it can be concluded in accordance with the hypothesis, namely: there is a relationship of parenting with the head shape of infants aged 0-6 months. The strength of the relationship is perfect correlation and the relationship is negative or inversely proportional. Parenting is seen from the baby's sleeping position, baby's sleeping pad, breastfeeding position and baby's head pad.

The most influence on babies is the baby's sleeping position, the most common sleeping position of the baby is supine because of the limited motor skills of the baby. So that the baby has not been able to change position if it is not helped by an adult. The use of sleeping mats, head pads and daily parenting affect changes in the shape of the baby's head.

\section{Reference}

Apta. 2007. Deformational Plagiocephaly \& Cranial Remolding In Infants.

Arlene, E. 1997.Bayi Pada Tabun Pertama : Apa Yang Anda Hadapi Per Bulan. Jakarta: Arcan.

Blair, P. S., \& Ball, H. L. (2004). The Prevalence And Characteristics Associated With Parent-Infant Bed-Sharing In England. Archives Of Disease In Childhood, 89(12), 1106-1110.

Diana, F. M. 2010. Pemantauan Perkembangan Anak Balita. Jurnal Kesehatan Masyarakat. Vol. 4, No. 2

Elianora, D., Sutardjo, I., \& Rianto, B. U. 2011. Bentuk Kepala Dan Wajah Pada Anak Retardasi Mental Usia 
6-12 Tahun Suku Jawa. Jurnal Kedokteran Gigi, 7-13.

Hastuti, D., Alfiasari, \& Chandriyani. (2010). Nilai Anak , Stimulasi Psikososial , Dan Perkembangan Pangan Di Kabupaten Banjarnegara, Jawa Tengah, 3(1), 27-34.

Hummel, P., \& Fortado, D. (2006). Impacting Infant Head Shapes. Official Journal of The National Association Of Neonatal Nurses.

Hutchison, B. L., Hutchion, L. A. ., Thompson, J. M. ., \& Mitchell, E. A. (2004). Plagiocephaly And Brachycephaly In The First Two Years Of Life: A Prospective Cohort Study. Pediatrics, 114(4), 970-980.

Iqbal, M. (2013). Pengembangan Model Kursi Bagi Ibu Menyusui Yang Ergonomis Berdasarkan Ukuran Antropometri (Uji Coba Di Kelurahan Pisangan Ciputat Timur) Tahun 2013. Program Studi Kesehatan Masyarakat Fakultas Kedokteran Dan Ilmu Kesehatan Universitas Islam Negeri Syarif Hidayatullah Jakarta.

Kharmina, Niniek. 2011. Hubungan Antara Tingkat Pendidikan Orang Tua Dengan Orientasi Pola Asub Anak Usia Dini.

Kusuma, R. (2012). Hubungan Antara Tingkat Pengetahuan Ibu Tentang Tumbuh Kembang Anak Dan Perkembangan Motorik Halus Balita Di Wilayah Kerja Puskesmas Penumping.

Lukmasari, Adriana Dkk.2017. Hubungan Antara Gangguan Tidur Dengan Gangguan Mental Emosional Anak Usia 4-6 Tahun Di Semarang.
Mccoy, R. C., Hunt, C. E., Corwin, M. J., Willinger, M., Hoffman, H., \& Mitchell, A. A. (2004). Frequency Of Bed Sharing And Its Relationship To Breastfeeding. Developmental \& Behavior Pediatrics, 25(3).

Moore, P. 2016. The Natural Baby Solution: Use Your Child's Internal Sleep Rhythms For Better Nights And Naps. Workman Publishing.

M.T. Indiarti. 2008. A To Z The Golden Age. Yogyakarta: Andi Yogyakarta.

Nurlia, R.S. 2014. Hubungan Kebiasaan Tidur Bayi Dengan Bentuk Kepala Bayi.

Putri, Dwi P Dan Soebadi, Amanda. (2014, Mei 09).Perawatan Bayi Baru Lahir. Retrieved.

Proverawati, Atikah Dan Rahmawati, Eni. 2010. Kapita Selekta Asie Menyusui.Yogyakarta: Nuha Medika.

Speltz, M. L., Heike, C., Cunningham, M., Gray, K., \& Starr, J. (2012, Desember 24). Developmental Delays Found In Children With Deformational Plagiochepaly.

Swarjana, I Ketut. 2016. Statistika Kesehatan. Yogyakarta: C.V Andi Offset.

Usman, Hastuti Dkk. 2014.Pertumbuhan Dan Perkembangan Anak Usia 324 Bulan Di Daerah Konflik. Jurnal Kesehatan Masyarakat Nasional. Vol. 9, No. 1

Waani, D. Z., \& Pusmaika, R. 2015. Pengetahuan Ibu Tentang Tumbuh Kembang Bayi Usia 0-1 Tabun Di Kampung Sabi Kabupaten Tangerang. Jurnal Bina Cendekia Kebidanan, 1 No 